Review

\title{
Actions of Bisphenol A on Different Feto-Maternal Compartments Contributing to Preterm Birth
}

\author{
Manuel S. Vidal, Jr. ${ }^{1, *}{ }^{\mathbb{D}}$, Ramkumar Menon ${ }^{2} \mathbb{D}$, Gracia Fe B. Yu ${ }^{3}\left(\mathbb{D}\right.$ and Melissa D. Amosco ${ }^{4}$ \\ 1 College of Medicine, University of the Philippines Manila, Manila 1000, Philippines \\ 2 Division of Basic Science and Translational Research, Department of Obstetrics and Gynecology, \\ The University of Texas Medical Branch at Galveston, Galveston, TX 77555, USA; ra2menon@utmb.edu \\ 3 Department of Biochemistry and Molecular Biology, University of the Philippines Manila, \\ Manila 1000, Philippines; grafebyu@gmail.com \\ 4 Department of Obstetrics and Gynecology, Philippine General Hospital, University of the Philippines Manila, \\ Manila 1000, Philippines; mdamosco@up.edu.ph \\ * Correspondence: msvidal1@up.edu.ph
}

Citation: Vidal, M.S., Jr.; Menon, R.; Yu, G.F.B.; Amosco, M.D. Actions of Bisphenol A on Different Feto-Maternal Compartments Contributing to Preterm Birth. Int. J. Mol. Sci. 2022, 23, 2411. https:// doi.org/10.3390/ijms23052411

Academic Editor: Jerome

F. Strauss III

Received: 5 January 2022

Accepted: 10 February 2022

Published: 22 February 2022

Publisher's Note: MDPI stays neutral with regard to jurisdictional claims in published maps and institutional affiliations.

Copyright: (C) 2022 by the authors. Licensee MDPI, Basel, Switzerland. This article is an open access article distributed under the terms and conditions of the Creative Commons Attribution (CC BY) license (https:// creativecommons.org/licenses/by/ $4.0 /$ )

\begin{abstract}
Preterm birth remains to be one of the most prevalent obstetric complications worldwide. Since there are multiple etiological factors associated with this disease process, an integrative literature search in PubMed and Scopus databases on possible mechanism of action and effect of bisphenols on exposure on human or animal placental samples in preterm birth was conducted. From 2332 articles on initial literature search, 63 studies were included for full data extraction. Altogether, several pathways were shown to be possibly affected by bisphenols, leading to dysregulations in structural and endocrine foundation in the placenta, potential induction of senescence and failure of decidualization in the decidua, and possible propagation of inflammation in the fetal membranes. Combined, these actions may eventually counteract bisphenol-induced relaxation of the myometrium and promote contractility alongside fetal membrane weakening. In totality, these individual impairments in gestation-critical processes may lead to failure of maintenance of pregnancy, and thus effecting preterm birth.
\end{abstract}

Keywords: bisphenol; BPA; preterm birth; endocrine-disrupting compounds

\section{Introduction}

Annually, 15 million infants are born prior to 37 weeks of gestation, defined by the World Health Organization (WHO) as preterm birth (PTB). Annual rates range from 5-18\% and is the top cause of mortality among children $<5 \mathrm{yr}$ of age [1]. Short-term complications may arise and lead to hospital-acquired infections, intraventricular hemorrhage, and necrotizing enterocolitis [2]. Long-term morbidities such as brain injury and abnormal brain development, cardiovascular, and metabolic abnormalities can be apparent down the line and persist until adolescence [3].

About half of preterm births (PTB) are of spontaneous or idiopathic etiologies, in contrast with preterm rupture of membranes (about a third of PTB cases) or elective preterm deliveries (about a fifth of PTB cases). These pathways are not mutually exclusive of each other, since there are redundancies in downstream effectors for each factor listed; moderate changes brought upon by a single factor may also not be adequate to bring about the definitive outcome of premature delivery [4,5]. Despite multiple different etiologies, the common pathway that allows for the early termination of pregnancy comes down to the generation of synchronous and forceful myometrial contractions and the remodeling of the cervical tract to dilatation and effacement similar to the normal physiological process of labor. Since spontaneous PTBs comprise the majority of these cases, determination of the exact pathophysiology becomes an important endeavor to allow possible interventions that can prevent PTB. 
Pollutant exposure is one of the proposed etiologies for spontaneous preterm birth [6,7]. In particular, bisphenols, one of the most prevalent pollutants in the environment, have been associated with a risk for decreased gestational age and preterm birth across multiple studies in different countries [8-11]. The main congener bisphenol A (BPA) is massively produced annually, with more than 6 billion pounds of yield every year used in food and beverage containers as well as epoxy resins for commercial products [12-14]. An alternative congener, bisphenol S (BPS), has also been synthesized and is currently used in containers, paper items, and hygiene products [15-18]. A recent meta-analysis summarizing papers from major databases published since inception to 2020 regarding BPA exposure and preterm birth highlighted that higher BPA exposure (median or geometric mean concentration $>2.16 \mathrm{ng} / \mathrm{mL}$ ) is linked to almost a two-fold risk of preterm birth as well as decreased gestational period. The association is significant especially for the third trimester elevated bisphenol levels, suggesting that this may be the critical window as to which BPA exerts its effects [19]. However, studies have been limited regarding their specific mechanisms of action in the feto-maternal unit.

In this light, this review explores the potential role of bisphenols in contributing towards a preterm birth phenotype. We will review pieces of evidence from various experimental models regarding observed molecular mechanisms and discuss the possible pathways in which these bisphenols may act to bring about preterm birth. A deeper understanding of the pathophysiology of risk factors associated with premature delivery may aid researchers, physicians, and policymakers in developing primary, secondary, and tertiary preventive measures.

\section{Results and Discussion}

\subsection{Search Strategy Employed}

After literature search and applying our inclusion and exclusion criteria, we included a total of 63 original papers for full data abstraction (Figure 1). Outcomes manually collected include type of model used, dose of bisphenols used, and effects observed with significance $(p<0.05)$ (Tables 1-3). Due to intermodel congruence of effects, we have designated strong evidences for the following: proliferation, trophoblast motility, trophoblast and placenta morphology, and CRH production in the placenta; inflammation and ER expression in the decidua; and uterine weight, thickness, and contractility in the myometrium. The rest of the effects have been designated as either limited or inconclusive evidence. The data are synthesized in the following subsections of the discussion that follows.

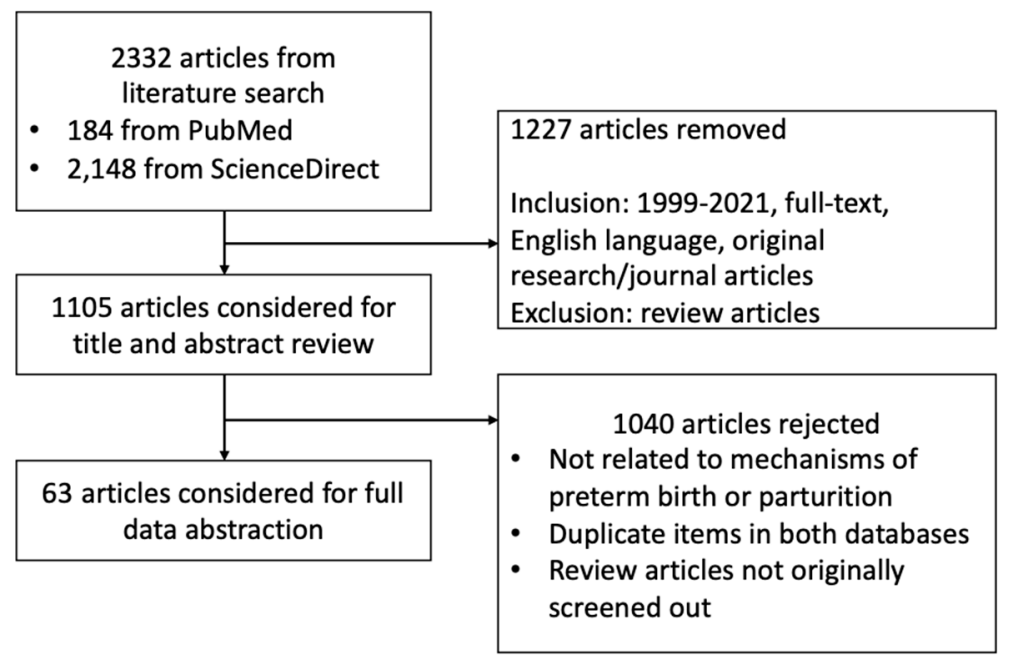

Figure 1. Search strategy employed. 
Table 1. Summary of studies delineating effects of BPA in the placenta.

\begin{tabular}{|c|c|c|c|c|c|}
\hline & Summary of Effects & References & Models Used & Strength & Notes \\
\hline Proliferation & $\begin{array}{c}\text { Increased-10-5-10 } \mu \mathrm{M} \\
\text { No effect- }-0.1-50 \mu \mathrm{M} ; \\
\text { Decreased-10 }-10^{-4}-1 \mathrm{M} ; \geq 100 \mu \mathrm{M}\end{array}$ & $\begin{array}{c}\text { Benachour } 2007 \\
\text { Spagnoletti } 2015 \\
\text { Morice } 2011 \\
\text { Morck } 2010 \\
\text { Basak } 2018 \\
\text { Greca } 2019 \\
\text { Greca } 2020 \\
\text { Profita } 2021\end{array}$ & $\begin{array}{c}\text { Embryonic } 293 \text { cells } \\
\text { HTR-8/SVneo cells } \\
\text { JEG-3, BeWo cells } \\
\text { BeWo cells } \\
\text { HTR-8/SVneo cells } \\
\text { BeWo cells } \\
\text { BeWo cells } \\
\text { HTR-8/SVneo cells }\end{array}$ & STRONG & $\begin{array}{c}\text { Different cell lines vary in the concentrations } \\
\text { wherein increased proliferation occurs, but } \\
\text { higher concentrations } \geq 100 \mu \mathrm{M} \text { are } \\
\text { consistently cytotoxic } \\
\text { Cell number of BPA-treated cells was } \\
\text { significantly decreased when treated with } \\
\text { G15, a GPr30 inhibitor }\end{array}$ \\
\hline $\begin{array}{l}\text { Placenta } \\
\text { morphology }\end{array}$ & $\begin{array}{c}\text { Decreased labyrinthine zones, thinner } \\
\text { spongiotrophoblasts-200 } \mu \mathrm{g}-50 \mathrm{mg} / \mathrm{kg} / \text { day } \\
\text { Decreased ratio of spongiotrophoblast zone to } \\
\text { giant cell area-200 } \mu \mathrm{g} / \mathrm{kg} \\
\text { Increased total vessel area- } 50 \mathrm{mg} / \mathrm{kg} / \text { day }\end{array}$ & $\begin{array}{l}\text { Tachibana } 2007 \\
\text { Tait } 2015 \\
\text { Lan } 2017 \\
\text { Chu } 2018 \\
\text { Mao } 2020 \\
\text { Gwon } 2020 \\
\end{array}$ & $\begin{array}{c}\text { Mouse placenta } \\
\text { Mouse placenta } \\
\text { HTR-8/SVneo cells } \\
\text { JEG-3 cells } \\
\text { Mouse placenta } \\
\text { Mouse placenta } \\
\end{array}$ & STRONG & \\
\hline $\begin{array}{l}\text { Trophoblast } \\
\text { morphology }\end{array}$ & $\begin{array}{l}\text { Increased syncytin and cell fusion- }-0.05 \mu \mathrm{M} \\
\text { Decreased villous outgrowth-0.1 to } 50 \mu \mathrm{M} \\
\text { Increased villous outgrowth-10 }-10 \mathrm{M} \text { Reduced } \\
\text { syncytialization }-0.5 \mathrm{mg} / \mathrm{kg} / \text { day, } 1 \mathrm{uM}\end{array}$ & $\begin{array}{l}\text { Tait } 2015 \\
\text { Narciso } 2019 \\
\text { Gao } 2019\end{array}$ & $\begin{array}{l}\text { Mouse placenta } \\
\text { BeWo cells } \\
\text { JEG-3 cells }\end{array}$ & STRONG & $\begin{array}{c}\text { Increased villous outgrowth observed for } \\
\text { trophoblast spheroid cell models; decreased } \\
\text { villous outgrowth in 2D trophoblast cell } \\
\text { cultures }\end{array}$ \\
\hline $\begin{array}{c}\text { CRH } \\
\text { production }\end{array}$ & $\begin{array}{l}\text { Increased CRH expression-200 mg/kg, } \\
\qquad 25-50 \mu \mathrm{M}\end{array}$ & $\begin{array}{l}\text { Huang } 2012 \\
\text { Tan } 2013\end{array}$ & $\begin{array}{l}\text { JEG-3 cells } \\
\text { Mouse placenta }\end{array}$ & STRONG & $\begin{array}{l}\text { At } 1-50 \mu \mathrm{M} \text {, increasing p-PKA, p-PKCalpha, } \\
\text { which may mediate CRH expression }\end{array}$ \\
\hline Steroidogenesis & $\begin{array}{c}\text { Decreased CYP11A1, CYP19-10-3-100 } \mu \mathrm{M} \\
\text { Decreased progesterone, estradiol-10-3 }-1 \mu \mathrm{M} \\
\text { Decreased aromatase-5-1000 } \mu \mathrm{M} \text { Increased } \\
\text { CYP1A1-10-50 } \mu \mathrm{M} \\
\text { No effect on serum progesterone in } \\
\text { sheep-0.5 mg } / \mathrm{kg} / \text { day }\end{array}$ & $\begin{array}{c}\text { Benachour } 2007 \\
\text { Nativelle-Serpentini } 2003 \\
\text { Huang and Leung } 2009 \\
\text { Chu } 2018 \\
\text { Xu } 2019\end{array}$ & $\begin{array}{l}\text { Embryonic } 293 \text { cells } \\
\text { JEG-3 cells } \\
\text { JEG-3 cells } \\
\text { JEG-3 cells } \\
\text { JEG-3 cells }\end{array}$ & LIMITED & $\begin{array}{l}\text { In JEG-3 cells, no difference with CYP19 } \\
\text { production }\end{array}$ \\
\hline MMPs & $\begin{array}{c}\text { Decreased MMP2, MMP9-10 }-3-100 \mu \mathrm{M} \\
\text { Increased MMP9-0.1-10 } \mu \mathrm{M}\end{array}$ & $\begin{array}{l}\text { Wang } 2015 \\
\text { Wei } 2020\end{array}$ & $\begin{array}{c}\text { BeWo cells } \\
\text { HTR-8/SVneo cells }\end{array}$ & LIMITED & \\
\hline
\end{tabular}


Table 1. Cont.

\begin{tabular}{|c|c|c|c|c|c|}
\hline & Summary of Effects & References & Models Used & Strength & Notes \\
\hline TIMP & $\begin{array}{c}\text { Increased TIMP1, TIMP2-10-3-100 } \mu \mathrm{M} \\
\text { Decreased TIMP3 }-10-50 \mu \mathrm{M}\end{array}$ & $\begin{array}{l}\text { Lan } 2017 \\
\text { Wang } 2015 \\
\text { Wei } 2020\end{array}$ & $\begin{array}{l}\text { HTR-8/SVneo cells } \\
\text { BeWo cells } \\
\text { HTR-8/SVneo cells }\end{array}$ & LIMITED & \\
\hline miR-146a & Increased $-25 \mathrm{ng} / \mu \mathrm{L}$ & $\begin{array}{l}\text { Avissar-Whiting } 2010 \text { de } \\
\text { Felice } 2015\end{array}$ & $\begin{array}{l}\text { SV40 cells } \\
\text { Human placenta }\end{array}$ & LIMITED & $\begin{array}{c}\text { miR-146a was the only miRNA validated by } \\
\text { qRT-PCR as significantly upregulated in } \\
\text { both 3A and HTR- } 8 \text { cells with BPA treatment } \\
\text { at } 25 \mathrm{ng} / \mu \mathrm{L}\end{array}$ \\
\hline $\begin{array}{l}\text { Other } \\
\text { hormone } \\
\text { production }\end{array}$ & $\begin{array}{c}\text { Decreased serotonin-200 } \mu \mathrm{g} / \mathrm{kg} \\
\text { Increased dopamine-200 } \mu \mathrm{g} / \mathrm{kg} \\
\text { Decreased B-hCG- } 10^{3}-10^{8} \mu \mathrm{M} \\
\text { Increased testosterone } \\
\text { concentrations-20-200 } \mathrm{mg} / \mathrm{kg} / \text { day }\end{array}$ & $\begin{array}{l}\text { Morck } 2010 \\
\text { Tan } 2013 \\
\text { Mao } 2020\end{array}$ & $\begin{array}{l}\text { BeWo cells } \\
\text { Mouse placenta } \\
\text { Mouse placenta }\end{array}$ & LIMITED & $\begin{array}{l}\text { Not necessarily concluding towards preterm } \\
\text { birth }\end{array}$ \\
\hline $\begin{array}{l}\text { Apoptosis- } \\
\text { related }\end{array}$ & $\begin{array}{c}\text { Increased apoptosis- }-0.01-0.1 \mu \mathrm{M} \\
\text { Increase caspase-3 production }-10^{-6} \mu \mathrm{M} \\
\text { Decreased caspase-3 production }-9 \mu \mathrm{M}\end{array}$ & $\begin{array}{c}\text { Morice } 2011 \\
\text { Narciso } 2019\end{array}$ & $\begin{array}{l}\text { JEG-3, BeWo cells } \\
\text { BeWo cells }\end{array}$ & INCONCLUSIVE & \\
\hline $\begin{array}{l}\text { Oxidative } \\
\text { stress }\end{array}$ & $\begin{array}{c}\text { Increased ROS production- } 50-500 \mu \mathrm{M} \\
\text { Increased HSP70, Bcl2-0.9 to } 9.0 \mu \mathrm{M} \text { Decreased } \\
\text { GSH-0.9 to } 9.0 \mu \mathrm{M} \\
\text { Increased Nrf- } 9.0 \mu \mathrm{M}\end{array}$ & $\begin{array}{c}\text { Ponniah } 2015 \\
\text { Perez-Albaladejo } 2017\end{array}$ & $\begin{array}{l}\text { BeWo cells } \\
\text { JEG-3 cells }\end{array}$ & INCONCLUSIVE & $\begin{array}{l}\text { Decrease in GSH + increased ROS } \\
\text { production increases oxidative damage, } \\
\text { while Nrf, HSP70, and Bcl2 production may } \\
\text { be counterregulatory measures }\end{array}$ \\
\hline Inflammation & $\begin{array}{c}\text { Decreased TNF-alpha- }-1.4 \times 10^{-6} \text { to } 0.04 \mu \mathrm{M} \\
\text { Increased IL-6-1-10 } \mu \mathrm{M} \\
\text { Increased IL-1B-0.001-10 } \mu \mathrm{M}\end{array}$ & $\begin{array}{c}\text { Benachour and Aziz } 2009 \\
\text { Arita } 2019\end{array}$ & $\begin{array}{l}\text { Human primary } \\
\text { cytotrophoblasts } \\
\text { Placental explants }\end{array}$ & INCONCLUSIVE & \\
\hline PR receptor & Decrease in PR expression $-2 \mu \mathrm{g} / \mathrm{kg} /$ day & Imanishi 2003 & Mouse placenta & INCONCLUSIVE & $\begin{array}{l}\text { Decrease in PR expression was embryo } \\
\text { sex-selective }\end{array}$ \\
\hline ER receptor & $\begin{array}{l}\text { BPA binds to ERRg about } 100 \text { times greater than } \\
\text { to ERa and Erb }\end{array}$ & Takeda 2009 & Human placenta & INCONCLUSIVE & $\begin{array}{l}\text { May provide alternative hypothesis for a } \\
\text { pathway for other BPA actions other than } \\
\text { classical steroid receptors }\end{array}$ \\
\hline ERK1/2 & Increased $\mathrm{p}$-ERK-10 $-3-1 \mu \mathrm{M}$ & $\begin{array}{l}\text { Chu } 2018 \\
\text { Lan } 2017\end{array}$ & $\begin{array}{c}\text { JEG-3 cells } \\
\text { HTR-8/SVneo cells }\end{array}$ & INCONCLUSIVE & $\begin{array}{l}\text { treatment with the extracellular } \\
\text { signal-regulated kinase (ERK1/2) inhibitor } \\
\text { U0126 or the PI3K inhibitor LY294002 for } \\
24 \mathrm{~h} \text { abolished the BPA-induced } \\
\text { phosphorylation of ERK and Akt }\end{array}$ \\
\hline
\end{tabular}


Table 1. Cont.

\begin{tabular}{|c|c|c|c|c|c|}
\hline & Summary of Effects & References & Models Used & Strength & Notes \\
\hline Akt & Increased p-Akt-0.01 $\mu \mathrm{M}$ & $\begin{array}{l}\text { Lan } 2017 \\
\text { Greca } 2020\end{array}$ & $\begin{array}{l}\text { HTR-8/SVneo cells } \\
\text { BeWo cells }\end{array}$ & INCONCLUSIVE & $\begin{array}{l}\text { treatment with the extracellular } \\
\text { signal-regulated kinase (ERK1/2) inhibitor } \\
\text { U0126 or the PI3K inhibitor LY294002 for } \\
24 \mathrm{~h} \text { abolished the BPA-induced } \\
\text { phosphorylation of ERK and Akt }\end{array}$ \\
\hline $\begin{array}{l}\text { PAG1 and } \\
\text { PSPB }\end{array}$ & $\begin{array}{c}\text { Decreased serum } \\
\text { concentration-0.5 mg/kg/day }\end{array}$ & Gingrich 2018 & Sheep placenta & INCONCLUSIVE & \\
\hline Exosomes & $\begin{array}{c}\text { Increased placental exosome expression of } \\
\text { HMGB1, caspase 4, MAPK14 expression-20 } \mu \mathrm{M}\end{array}$ & Sheller-Miller 2020 & $\begin{array}{l}\text { Human placental } \\
\text { exosomes }\end{array}$ & INCONCLUSIVE & \\
\hline
\end{tabular}

Table 2. Summary of studies delineating effects of BPA in the decidua.

\begin{tabular}{|c|c|c|c|c|c|}
\hline & Summary of Effects & References & Model Used & Strength & Notes \\
\hline Inflammation & $\begin{array}{c}\text { Increased LIF, IL-10-10 } \mu \mathrm{M} \\
\text { Decreased PAI-1, TNFa-10 } \mu \mathrm{M} \\
\text { Decreased CXCL8, IL-6, CCL11-1-10 } \mu \mathrm{M} \\
\text { Increased CXCL6-1-10 } \mu \mathrm{M} \\
\text { Increased IL-6-10-6-0.001 } \mu \mathrm{mol} \\
\text { Increased I-kB, nF-kB, } \\
\text { IL-1B-10-6-0.001 } \mu \mathrm{mol}\end{array}$ & $\begin{array}{l}\text { Li } 2017 \\
\text { Cho } 2018 \\
\text { Fan } 2020 \\
\text { Xiong } 2020\end{array}$ & $\begin{array}{l}\text { Human decidual stromal cells } \\
\text { Human endometrial (EM) } \\
\text { cells } \\
\text { Human EM cells, JEG-3 cells } \\
\text { Human EM cells }\end{array}$ & STRONG & $\begin{array}{c}\text { Effects on IL-6 may be discordant due to two } \\
\text { different laboratory setups; additionally, total } \\
\text { concentration of BPA was not noted in Cho 2018, } \\
\text { precluding us from identifying at what exact } \\
\text { concentration is the IL-6, I-kB, nF-kB, and IL-1B } \\
\text { increase noted. }\end{array}$ \\
\hline ER expression & $\begin{array}{c}\text { Decreased-50-100 } \mu \mathrm{M}, 0.5 \\
\mathrm{mg} / \mathrm{kg} / \text { day }-20 \mathrm{mg} / \mathrm{kg} / \text { day } \\
\text { Increased ERa-10-6-1 } \mu \mathrm{M} \\
\text { Increased ERB-0.001 } \mu \mathrm{M}\end{array}$ & $\begin{array}{l}\text { Varayoud } 2008 \\
\text { Aghajanova and } \\
\text { Giudice } 2011 \\
\text { Mannelli } 2015 \\
\text { Cho } 2018\end{array}$ & $\begin{array}{l}\text { Human uterine stromal cells } \\
\text { Human EM cells } \\
\text { Placental explant } \\
\text { Human EM cells }\end{array}$ & STRONG & $\begin{array}{l}\text { Total concentration of BPA was not noted in Cho } \\
\text { 2018, precluding us from identifying at what exact } \\
\text { concentration is the ERa increase noted. } \\
\text { SMRT corepressor decreases ER and PR receptivity } \\
\text { as per Varayoud } 2008\end{array}$ \\
\hline PR expression & Increased-50 $\mu \mathrm{g} / \mathrm{kg} /$ day, $1 \mu \mathrm{M}$ & Aldad 2011 & $\begin{array}{l}\text { Human EM cells, Ishikawa } \\
\text { cells }\end{array}$ & LIMITED & $\begin{array}{c}\text { SMRT corepressor decreases ER and PR receptivity } \\
\text { as per Varayoud } 2008 \\
\text { No effect as per Aghajanova and Giudice } 2011\end{array}$ \\
\hline $\begin{array}{l}\text { Decidual } \\
\text { proliferation }\end{array}$ & $\begin{array}{c}\text { Decreased-50-100 } \mu \mathrm{M}, 0.5 \mathrm{mg} / \mathrm{kg} / \text { day to } \\
20 \mathrm{mg} / \mathrm{kg} / \text { day } \\
\text { Increased- } 0.01 \mu \mathrm{M}\end{array}$ & $\begin{array}{l}\text { Varayoud } 2008 \\
\text { Aghajanova and } \\
\text { Giudice } 2011\end{array}$ & $\begin{array}{l}\text { Human uterine stromal cells } \\
\text { Human EM cells }\end{array}$ & LIMITED & $\begin{array}{l}\text { No effect on viability as per Mannelli et al.; may be } \\
\text { due to differences in setups }\end{array}$ \\
\hline
\end{tabular}


Table 2. Cont.

\begin{tabular}{|c|c|c|c|c|c|}
\hline & Summary of Effects & References & Model Used & Strength & Notes \\
\hline Steroidogenesis & $\begin{array}{c}\text { Decreased P450scc-50-100 } \mu \mathrm{M} \\
\text { Decreased 17BHSD1-50-100 } \mu \mathrm{M} \\
\text { Increased SMRT-0.5 mg/kg/day and } \\
20 \mathrm{mg} / \mathrm{kg} / \text { day }\end{array}$ & $\begin{array}{l}\text { Aghajanova and } \\
\text { Giudice } 2011 \\
\text { Varayoud } 2008\end{array}$ & $\begin{array}{c}\text { Human EM cells } \\
\text { Human uterine stromal cells }\end{array}$ & LIMITED & \\
\hline IGFBP-1 & Increased $-10^{-8}$ to $10^{-11} \mu \mathrm{M}, 50 \mu \mathrm{M}$ & $\begin{array}{l}\text { Aghajanova and } \\
\text { Giudice } 2011 \\
\text { Forte } 2015 \\
\text { Fan } 2020\end{array}$ & $\begin{array}{c}\text { Human EM cells } \\
\text { Human EM cells } \\
\text { Human EM cells, Ishikawa cells }\end{array}$ & LIMITED & $\begin{array}{l}\text { No effect on IGFBP-1 secretion as per Mannelli et al.; } \\
\text { may be due to differences in setups }\end{array}$ \\
\hline PRL & $\begin{array}{c}\text { Increased-10 }-8-10^{-11} \mu \mathrm{M}, 0.1-10 \mathrm{uM} \\
\text { Decreased-0.1-88 } \mu \mathrm{M}\end{array}$ & $\begin{array}{l}\text { Forte } 2015 \\
\text { Mannelli } 2015 \\
\text { Olson } 2017 \\
\text { Fan } 2020 \\
\text { Xiong } 2020 \\
\end{array}$ & $\begin{array}{c}\text { Human EM cells } \\
\text { Placental explants } \\
\text { HuF cells } \\
\text { Human EM cells, Ishikawa cells } \\
\text { Human EM cells }\end{array}$ & LIMITED & $\begin{array}{c}\text { Same endometrial cells, but different effects, } \\
\text { perhaps due to different laboratory setups } \\
\text { At lower concentrations, PRL appears to be } \\
\text { increased, while for higher concentrations, PRL } \\
\text { appears to be decreased }\end{array}$ \\
\hline $\mathrm{ENaC}$ & Decreased-0.01-1 $\mu \mathrm{g} / \mathrm{mL}$ & Yuan 2018 & Mouse EM cells, Ishikawa cells & INCONCLUSIVE & \\
\hline SGK1 & Decreased-100 $\mu \mathrm{g} / \mathrm{kg}$ & Yuan 2018 & Mouse EM cells, Ishikawa cells & INCONCLUSIVE & \\
\hline Cell cycle & $\begin{array}{c}\text { Lower G0/G1 cycles, Higher G2/M } \\
\text { cycles-10-11 }-10^{-8} \mu \mathrm{M} \\
\text { Decreased CCND2-44 } \mu \mathrm{M}\end{array}$ & $\begin{array}{l}\text { Forte } 2015 \\
\text { Olson } 2017\end{array}$ & $\begin{array}{l}\text { Human EM cells } \\
\text { HuF cells }\end{array}$ & INCONCLUSIVE & \\
\hline Hoxa10/11 & Decreased-0.5-20 mg/kg/day & Varayoud 2008 & Human uterine stromal cells & INCONCLUSIVE & \\
\hline Egr1 & Increased-20-500 mg/kg & Kim 2017 & Mouse uterus & INCONCLUSIVE & $\begin{array}{l}\text { ERK1/2 and AKT were rapidly activated by BPA, } \\
\text { BPA-induced Egr1 expression is mediated by } \\
\text { ERK1/2, but not AKT phosphorylation }\end{array}$ \\
\hline p-ERK & Increased $-10^{-6}-0.001 \mu \mathrm{mol}$ & Cho 2018 & Human EM cells & INCONCLUSIVE & $\begin{array}{l}\text { Both appear to increase similarly, but ERK may be more } \\
\text { involved in the signaling process than Akt (Kim 2017) }\end{array}$ \\
\hline p-Akt & Increased $-10^{-6}-0.001 \mu \mathrm{mol}$ & Cho 2018 & Human EM cells & INCONCLUSIVE & \\
\hline p-JNK & Increased $-10^{-6}-0.001 \mu \mathrm{mol}$ & Cho 2018 & Human EM cells & INCONCLUSIVE & \\
\hline $\begin{array}{l}\text { Histone } \\
\text { methylation }\end{array}$ & 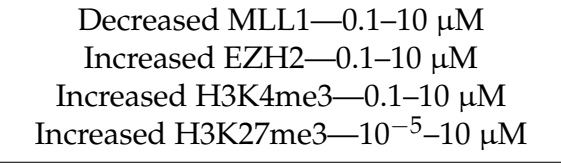 & Xiong 2020 & Human EM cells & INCONCLUSIVE & \\
\hline $\begin{array}{l}\text { Oxidative } \\
\text { stress }\end{array}$ & $\begin{array}{l}\text { Decreased SOD, catalase, } \\
\text { HO }-10^{-6}-0.001 \mu \mathrm{mol}\end{array}$ & Cho 2018 & Human EM cells & INCONCLUSIVE & $\begin{array}{l}\text { Total concentration of BPA was not noted in this } \\
\text { experiment; only picomolar values were given }\end{array}$ \\
\hline
\end{tabular}


Table 3. Summary of studies delineating effects of bisphenols in the myometrium

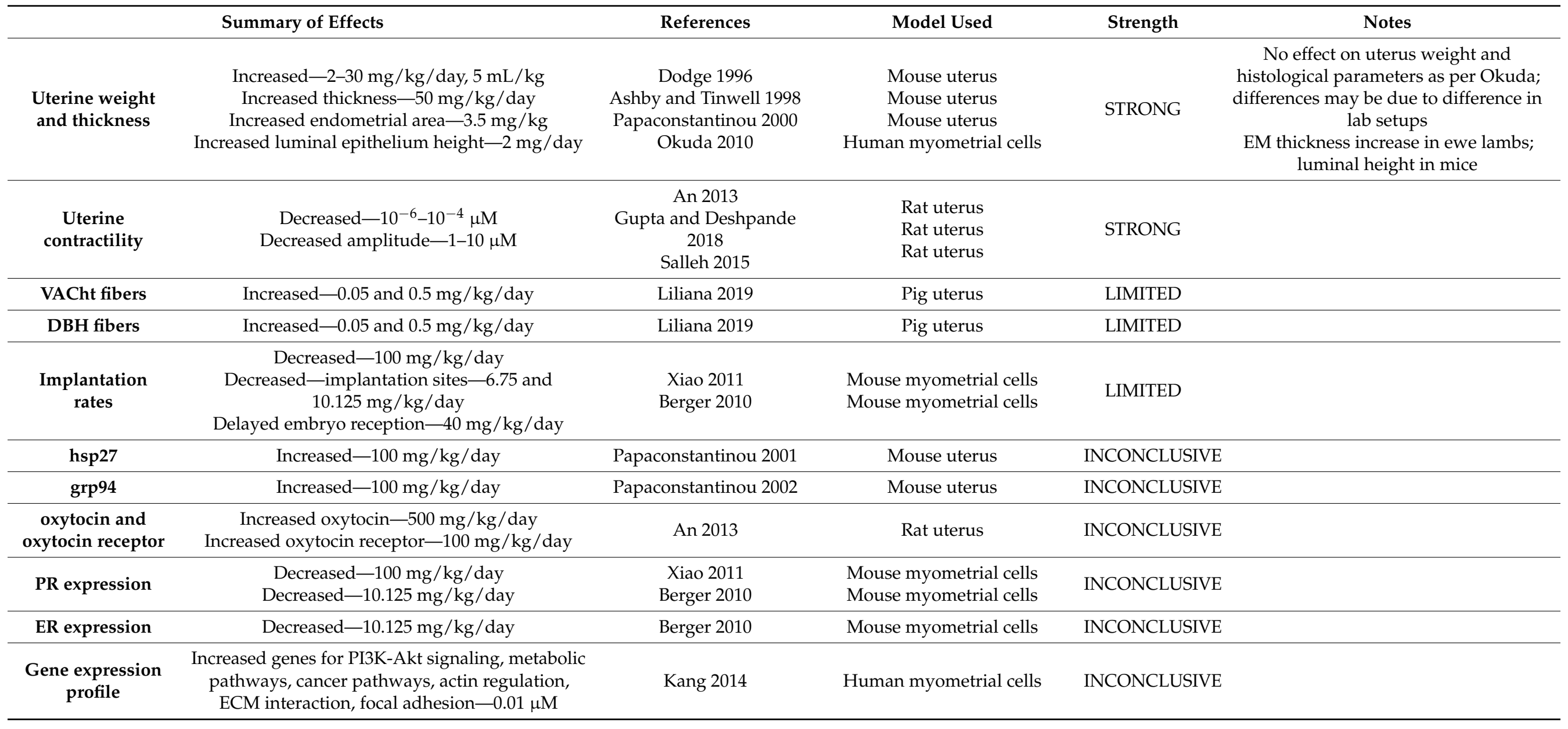




\subsection{Effects of Bisphenols on the Placenta}

BPA effects on various intrauterine tissues are examined primarily as an endocrine disruptor, although many other undetermined effects on "cell fate" may determine underlying pathways and biomarkers of its impact on determining pregnancy outcome. The placental cells express estrogen receptors (ERs), mainly $\operatorname{ER} \alpha$ and $\operatorname{Er} \beta$ [20]. This is important since estrogen is a particular signal for cellular growth and development. Reports vary in the effects of lower concentrations of bisphenols on cellular proliferation possibly initiated by the ER $\alpha$ pathway; increased proliferation has been observed from $10^{-5}$ up to $10 \mu \mathrm{M}$ [21-23]. Alternatively, BPA-induced estrogen function may be performed via non-classical receptors; one example is GPR30, a transmembrane receptor that is hypothesized to be critical for placentation [21]. In some cell models, such as HTR-8/Svneo cells and primary cytotrophoblast cells, there appears to be no effect at all $[24,25]$. Higher BPA doses have consistently demonstrated an observable decrease in proliferation and apparent cytotoxicity beyond 10-100 $\mu \mathrm{M}$ [26-29]. These cytotoxic effects may be mediated by the estrogen-related receptory1 (ERRy1), since abolishing the expression of ERRy1 via silencing RNA (siRNA) rescues trophoblast cells from reduced proliferation [22,30]. MicroRNAs (miRNAs) may also play nonclassical roles in the suppression of cell proliferation; miR-146a expression is induced by BPA in HTR-8 cells as well as in placentas of pregnant women, with stable overexpression leading to a significant decrease in proliferation [31,32]. Overall, it can be surmised that placental cellular proliferation is consistently suppressed at higher concentrations; effects on lower concentrations may vary depending on the cell type used and experimental setup [21-28].

Low concentrations of BPA $(50 \mathrm{nM})$ promote cell fusion [33]. However, high concentrations of BPA promote dysregulation of the normal placental phenotype. Long-term BPA exposure of rhesus monkey trophoblast stem cells reduced trophoblast invasion, even at non-toxic concentrations [26]. In mouse placenta, BPA causes a decrease in the labyrinthine and spongiotrophoblast zone proportions with narrowing of the intervillous spaces [34-37]. The exact mechanisms as to how this occurs seems to be debatable; matrix metalloproteinase-2/9 (MMP2/MMP9) seems to be involved, but upregulation or downregulation occurs depending on the model used [34,35,38,39].

BPA has also been reported to reduce blood flow throughout the uteroplacental unit through morphological vessel disruption in animal models, such as impairments in spiral remodeling and branching, and lumen narrowing that may lead to hypoperfusion [40,41]. BPA inhibits basal and vascular endothelial growth factors (VEGF) by downregulating mRNA expression of VEGF and lowering CpG methylation of gene promoters associated with oxidative stress in HTR8/SVneo cells [42,43]. Decreased migration and attachment have also been observed across a wide range of concentrations, which limit the optimal invasion necessary for sufficient placental formation $[24,26,35,38]$. Overall, the resulting gradual uteroplacental insufficiency from suboptimal placentation may provide inadequate oxygenation that can trigger eventual feto-maternal stress.

Interestingly, BPA decreases the levels of estrogen and progesterone production in cultured placental cells [28]. In JEG-3 cells, BPA has been shown to upregulate the protein expression of the CYP1A1 gene, important for detoxification of environmental toxins, and downregulate the protein expression of the CYP19A1 gene, a player in the in situ conversion of androgens to estradiol in the placenta [44,45]. Similarly, CYP11A1, which converts cholesterol to pregnenolone, was also demonstrated to be downregulated after BPA exposure. [28] There has also been a documented decrease in aromatase activity even in non-toxic BPA doses, suggesting that direct interaction of BPA with the gene product is possible $[46,47]$. Decreased hormone production in the placenta is paralleled by a decrease in ER and progesterone receptor (PR) expression and activity in higher doses [48-52]. However, the lack of exploration on in vivo models on steroidogenesis provides us with a limited view of the effects of BPA on steroid receptor expression.

A central player in parturition is the expression of corticotropin-releasing hormone $(\mathrm{CRH})$, classically leading to eventual myometrial contractions and decidual production of 
prostaglandins as an integral indicator of fetal stress [53-55]. In JEG-3 cells, CRH messenger RNA (mRNA) expression has been found to increase at concentrations of BPA $>25 \mu \mathrm{M}$, with downstream actions mediated by protein kinase $C$ as seen in mice placenta $[55,56]$. CRH also modulates placental steroidogenesis by upregulating enzymes involved in estrogen synthesis while decreasing progesterone production, assisting with the quiescence-tocontractility transition $[57,58]$. However, no mechanistic studies have been proposed yet regarding the relationship between preterm birth, bisphenols, and urocortins.

Inflammatory mediators in the placenta, such as interleukin (IL)- $1 \beta$ and IL-6, have been demonstrated to increase post-exposure to bisphenol in a dose-dependent manner [59]. In sheep placenta, there was a demonstrable increase in oxidative stress markers and IL-1 $\beta \mathrm{s}$ during mid-gestation [60]. These direct synthesis of prostaglandins and metalloproteinases, that leads to eventual parturition [61-63]. The placenta may respond via increasing antioxidant activity, such as post-exposure increases in glutathione levels; however, long-term inflammation may overcome any potential acute anti-inflammatory response [64]. However, most of the studies involving inflammatory signaling come from cellular studies, and so these remain inconclusive until validated in mice/humans.

Exposure to BPA has also been proven to cause dysregulation in protein cargo of placental exosomes, which are small extracellular vesicles hypothesized to perform signaling and/or effector actions between individual organs [65]. Proteomic analysis of placental exosomes from BPA-exposed explants showed upregulation in proteins biologically functional for organismal death, morbidity or mortality, and necrosis, and concomitant downregulation of proteins for cell viability and survival as well as migration and spread. Among them, p38 MAPK has been discussed extensively, since its packaging into exosomes may be correlated with cellular response for damage [66]. However, this is a relatively new subject and further experiments on human or animal tissues are needed to validate this response.

Overall, BPA has been shown to reduce cellular proliferation and growth in high doses $(\geq 10-100 \mu \mathrm{M})$, while affecting trophoblast motility and morphology $(1-100 \mu \mathrm{M})$ that may lead to reduction of placental blood flow. Other effects have been noted as well, such as reduction of steroidogenesis, impairment of syncytialization, activation of inflammation, and placental exosome changes; however, these variable effects across different models need to be validated in more robust endeavors.

\subsection{Effects of Bisphenols on the Decidua}

Bisphenols have been shown to induce inflammatory changes in the decidua. For instance, chronic BPA exposure reduced Hand2 expression, a transcription factor critical for decidualization. This may result in a decrease in IL-15 expression, leading to failure of uterine natural killer cells to eliminate senescent decidual cells $[67,68]$. This accumulation of senescent decidual cells may result in a local pro-inflammatory environment [69]. In human endometrial stromal cells (ESCs), BPA exposure induces expression of tumor necrosis factor alpha (TNF- $\alpha$ ), IL-6, and IL-1 $\beta$ [70]. The latter, along with thrombin, downregulates the expression of Hoxa10 and the associated Hoxa11 genes in decidual cells, leading to preterm labor [71]. IL-1 $\beta$ has also been shown to significantly amplify the expression of MMPs, resulting in a matrix-degrading cascade targeting the surrounding matrix [72]. IL-6 expression within the decidua promotes local monocyte differentiation into functional macrophages [73]. These inflammatory changes may contribute to overall prostaglandin production that leads to membrane weakening and eventual preterm birth.

Decidualization involves steroid receptor hormones interactions. BPA has been shown to upregulate levels of ERs and PRs upon exposure to low concentrations of BPA (up to $1 \mu \mathrm{M}$ ), but higher doses correlate with decreased expression [74-77]. Hoxa10 is also downregulated upon chronic BPA exposure, resulting in impaired steroid responsiveness of the decidual stroma; concomitant upregulation of steroid receptor corepressor SMRT also occurs in endometrial stromal cells in exchange for promotion of trophoblast invasion [78]. A fall in progesterone responsiveness may trigger a pro-inflammatory decidual response, 
potentially contributing to the overall senescent phenotype. Hoxa10 reductions are also correlated with increased enhancer of zeste homolog 2 (EZH2) and decreased mixedlineage leukemia 1 (MLL1), transcription factors responsible for decidualization [79]. EZH2 mediates gene suppression via histone methylation H3K27me3, while MLL1 allows for transcription via histone trimethylation $\mathrm{H} 3 \mathrm{~K} 4 \mathrm{me} 3$ [80]. As decidual cells are responsive to ER and PR expression changes, the aforementioned effects must take into consideration that levels may vary across multiple models. Overall, evidence points to the existence of a possible dose- and time-dependence on ER and PR expression in decidual cells upon BPA exposure, and these mechanisms should be further explored.

Steroidogenesis, which is naturally important for decidualization, is also affected by BPA exposure. In ESCs, exposure to BPA results in a decrease in P450 side-chain cleavage (P450scc) enzyme expression, which mediates cholesterol to pregnenolone conversion for progesterone and estrogen synthesis $[75,81]$. Moreover, hydroxysteroid-17 $\beta$-dehydrogenase 1 and 2 (HSD17 $\beta 1$ and HSD17 $\beta 2$ ) expression is also downregulated upon BPA exposure, interfering with estrone and estradiol interconversion [75].

Cell cycle arrest may be another factor that affects decidualization status upon bisphenol exposure. At lower concentrations $(0.01 \mathrm{nM}$ to $0.01 \mu \mathrm{M})$ BPA-exposed ESCs seem to be arrested at the G2/M phase [82]. However, at higher concentrations $(\sim 45 \mu \mathrm{M}-90 \mu \mathrm{M})$, BPA markedly downregulated the expression of CCND2, the gene encoding for cyclin D2, resulting to a significant fraction of cells arrested in the G1 phase [83,84].

All of these impairments in decidualization are reflected in alterations of decidualization markers. In ICR mice, oral administration of BPA in early pregnancy decreases the levels of desmin and serum/glucocorticoid regulated kinase 1 (SGK1) levels, proteins expressed by decidualizing cells [85]. In human endometrial cells, at low concentrations $(<0.01 \mu \mathrm{M})$, there is an observed increase in prolactin (PRL) and insulin-like growth factor binding protein 1 (IGFBP1) expression in ESCs [86]. However, at $1 \mu \mathrm{M}$, there is a significant reduction of mRNA levels of PRL [74]. At higher concentrations $(10 \mu \mathrm{M})$, the expression levels of both markers do not significantly differ versus control [86]. At even higher concentrations $(>50 \mu \mathrm{M})$, however, there was an increase in IGFBP1 levels but not that of PRL [75]. There seems to be a bimodal action of BPA on decidual markers, with concentrations at the window of relevance (between $0.01 \mu \mathrm{M}$ and $10 \mu \mathrm{M}$ ) providing suppression of decidual markers. However, more standardized experiments are warranted with regards to decidualization and bisphenol exposure.

BPA also induces the expression of decidual Egr1, a critical gene for decidualization under estrogen control [87,88]. Egr1 has been documented to be upregulated in maternal plasma of preterm delivery patients [89]. Decreased estrogen receptivity may lead to possible aberrant overexpression of the gene, leading to (1) inhibition of the decidualization process as evidenced by a significant decrease in decidual/trophoblast PRL-related protein (Dtprp), and (2) increase in Cox-2 expression that may result to excessive prostaglandin and metalloproteinase synthesis [88,90].

BPA effects on the decidua may also contribute to impaired placentation observed in the previous studies. A decrease in Hoxa10 in the decidua is critical to allow trophoblast invasiveness [91]. As we have concluded in the previous section, improvement of trophoblast invasion by decidual factors does not necessarily result in overall improved placentation. Excessive activity of MMPs post-exposure to bisphenol may lead to reductions of placental layers, as observed in the HTR-8/SVneo cells [35]. Decidual CXCL8 expression is evidently decreased by BPA exposure, leading to a decrease in trophoblast invasion in in vitro setups. Interestingly, this effect is rescued by the administration of an ER antagonist and a GPR30 antagonist, which connotes that these receptors may be involved in decidual-mediated impairment of invasion post-exposure to BPA [92].

Overall, changes in the decidua upon BPA exposure lead to inflammatory effects as well as an increase in ER expression as observed in different models. Other model-variable effects may include induction of decidual senescence, decreased decidual responsiveness 
to steroids, and activation of inflammation leading to prostaglandin and MMP synthesis; these remain to be established yet in other experiments.

\subsection{Effects of Bisphenols on the Myometrium}

Little is known about the effects of BPA on the myometrium, but it is generally observed that exposure to a wide range of concentrations (50-500 mg/ $\mathrm{kg} /$ day) in different routes of administration leads to a uterotrophic phenotype (increased myometrial and stromal thickness, and PCNA immunostaining) across multiple animal models [93-99]. The effects are hypothesized to be mediated both by ER- and non-ER-mediated pathways [100]. The latter involves nonclassical pathways, such as heat shock protein 72 (hsp72), hsp90 $\alpha$, and homologous glucose-regulated protein 94 (grp94) in ovariectomized mice. These chaperone proteins, aside from protein folding functions, have been associated with ER signaling and, indirectly, with uterotrophism [101].

An increase in uterine weight does not necessarily result in increased uterine contractile force. Curiously, bisphenol has been found to decrease the myometrial contractions in various experiments, despite increasing OXTR and OXT expression [102,103]. This dosedependent decrease in amplitude and frequency of contractions has been suggested to operate via (1)a nitric oxide-involving pathway, and (2)a vesicular acetylcholine transporter (VACht)-mediated pathway; however, these mouse- and porcine-related uterine changes remain to be replicated in human cells [104-106].

Moreover, the presence of uterotonins may counteract BPA-induced relaxation. In an ex vivo uterine contraction study using rat uterine tissue, the presence of prostaglandin F2 $\alpha$ or oxytocin in spite of BPA exposure restores the force of contraction in a dosedependent manner [103]. Purportedly, GPR30 activation may also be involved through an increase in oxytocin responsiveness and promotion of actin polymerization through hsp27 and MAPK phosphorylation [107,108]. Genes related to smooth muscle contractility and MAPK signaling have been also found to be upregulated in the presence of uterotonins in an ER-independent manner, although the exact molecular switch remains to be discovered $[109,110]$.

Additionally, a BPA-induced decrease in steroidogenesis in the placenta may result in the downregulation of Hoxa10/11 in the myometrium. Hoxa10/11, repressed by high progesterone levels, causes suppression of mRNAs of various mediators of contraction including the genes for Cx43, COX-2, IL-1 $\beta$, and IL-6 [111,112]. Increases in inflammatory cytokines may also provide a feed-forward downregulation of Hoxa10, which may lead to sufficient contractions in localized areas of the uterus, an increase in MMPs, and eventual preterm birth [112].

Overall, BPA has been consistently observed to increase uterine weight and uterine thickness and induce relaxation in myometrial cells across different models. In essence, we can surmise that all other actions by local units (placenta, decidua, and amnion cells) contribute a far greater effect, and may overcome myometrial relaxation; however, the hypothesis remains to be seen in actual experiments.

\subsection{Effects of Bisphenols on Fetal Membranes}

Very little data is known regarding the direct effects of bisphenols on fetal membranes despite knowledge of its transplacental transfer to the fetal compartment due to a lack of experiments [113]. Nonetheless, a few hypotheses can be generated through isolated studies on oxidative stress. In amnion epithelial cells (AECs), oxidative stress increases hsp70 and p38 MAPK packaging into exosomes; since BPA also induces placental oxidative stress and p38 MAPK exosome packaging, it may be hypothesized that BPA behaves similarly in AECs $[59,70,114]$. Inhibition of p38 MAPK activation results in senescence reversal and rescue from sterile inflammation $[115,116]$. AEC exosomes have been found to induce expression of Cox-43 and Cox-2 in myocytes after exposure to cigarette smoke extract, suggesting that packaged compounds inside AEC exosomes may be transported to other feto-maternal compartments and may trigger labor-associated changes [66]. 
Direct inflammation propagation from either decidua or placenta post-exposure to bisphenols may affect fetal membranes as well. In rhesus monkeys, for instance, IL-1 $\beta$ stimulates IL-17 production from chorioamniotic T-cells, propagating the inflammatory response in these layers [61]. On the other hand, IL-6, on its own, does not induce any inflammatory and cellular transition changes in AECs [117]. However, IL-6 stimulates the production of PGE2 with a concomitant decrease in PGDH in AECs, increasing prostaglandins within the fetal membranes especially with a continuous influx of IL-6 from other fetomaternal units [118]. Nonetheless, additional studies are warranted in order to validate the hypothesis that bisphenols may cause inflammation in fetal membranes.

\subsection{Limitations of the Study}

Naturally, due to the ubiquitous nature of BPA especially in commercial products, majority of the studies on the effects of bisphenols on preterm birth circle around BPA itself. Some congeners may act similarly; for instance, BPS exposure has been found to lead to impairment of trophoblast morphogenesis via reductions in e-cadherin expression and blockage of EGFR $[119,120]$. In some instances, however, these may not follow BPA mechanics; for instance, BPS has been demonstrated to be associated with a decrease in $\mathrm{CRH}$, opening the possibility that (1) different bisphenol analogs differentially act on CRH pathways or (2) CRH analogs such as urocortins may be affected by BPA exposure [121,122]. Moreover, in the context of varying models and physiological environments as to which BPA has been tested in, we cannot definitively conclude that these mechanisms are conserved in the feto-maternal tissues in preterm birth. Nonetheless, by aggregating evidences from these various experiments across different models, this paper provides a stepping stone as to which effects may be expected in actual patients. Hopefully, future experiments may delve deeper into the actions of BPA put forward in this paper and develop more robust methods to elucidate the mechanisms in human tissues. We also observed that majority of these experiments used concentrations that are higher than $2.16 \mathrm{ng} / \mathrm{mL}(9.5 \mathrm{nM})$, which is correlated with preterm birth as cited in a previous study. [20] Some studies have touched on this concentration, as seen in Table 1; these are the effects that may occur in human tissues, and future experiments should take this concentration into account.

\section{Conclusions}

Although there have been studies published regarding the possible mechanisms of actions of bisphenols that may contribute to preterm birth, there is a relative lack of coherence due to the use of various in vitro, in vivo, and ex vivo models due to human experimentation barriers. Future studies may be directed towards simulating prenatal and antenatal dosing in order to have a better insight towards short-term, and in particular, long-term effects of these compounds. Doses may also be standardized in terms of concentrations (i.e., calculation of actual human exposure levels) and routes of administration (i.e., either orally in animal models, or through a stable influx of steady-state concentrations in in vitro models). As mentioned, the mean concentration that correlates with preterm birth is around $>2.16 \mathrm{ng} / \mathrm{mL}$ or $9.5 \mathrm{nM}$; future experiments may rely on similar or higher values to initiate BPA effects for observation [20]. Lastly, since bisphenols have multiple modes of action across different feto-maternal units, future studies may utilize mechanistic animal models that parallel placental, decidual, myometrial, and fetal membrane endpoints that are duly changed in humans post-exposure to bisphenols. By taking into account the time-, concentration-, and cell-dependent mechanisms of action of bisphenols, these recommendations will help form a more robust notion on the exact pathophysiology of bisphenol exposure in relation to preterm birth.

Despite these obstacles, the bits and pieces of information that we gather from these studies should not be discounted. Altogether, several pathways were shown to be possibly affected by bisphenols, leading to dysregulations in structural and endocrine foundation in the placenta, potential induction of senescence and failure of decidualization in the decidua, and possible propagation of inflammation in the fetal membranes; combined, these actions 
may eventually counteract bisphenol-induced relaxation of the myometrium and promote contractility alongside fetal membrane weakening. In totality, these may lead to failure of maintenance of pregnancy that may lead to preterm birth (Figure 2).

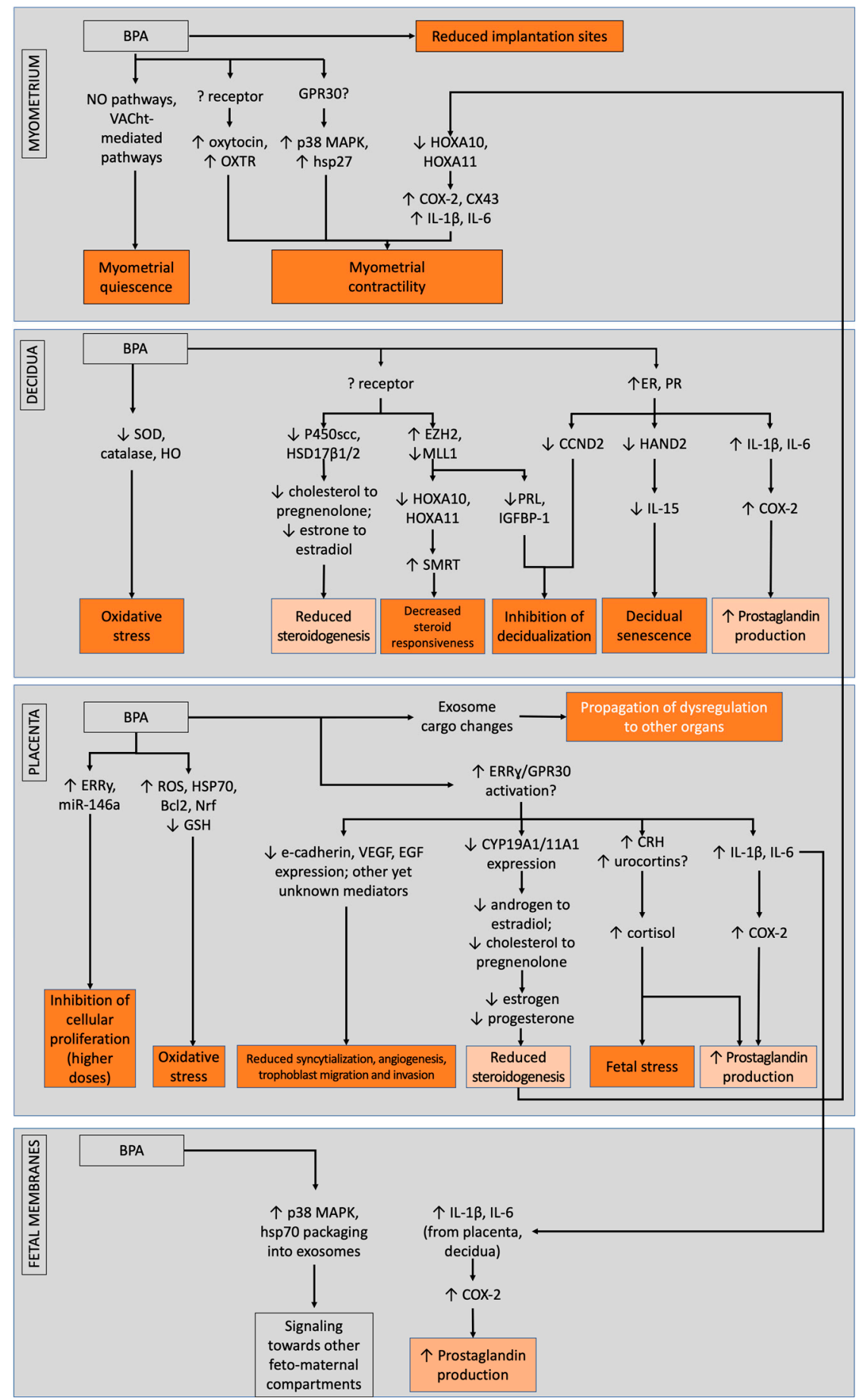

Figure 2. BPA and its mode of actions across different feto-maternal units that possibly contribute to preterm birth, separated between low- and high-dose actions. Light orange boxes denote similar modes of actions between different units, while dark orange boxes denote actions that contribute to the preterm phenotype. Overall, bisphenols cause impairments in the decidua, placenta, and fetal membranes that may counteract myometrial relaxation and promote fetal membrane weakening. 


\section{Materials and Methods}

\subsection{Search Strategy}

We conducted a literature search in PubMed and ScienceDirect databases that identify any articles regarding bisphenol and its effects on the myometrium, decidua, placenta, and/or fetal membranes. We used the search terms: bisphenol AND (decidua OR placenta OR myometri* OR amnion OR chorion OR trophoblast) AND (human OR animal OR mouse OR mice OR sheep OR monkey OR cell OR "in vitro") in the PubMed database. We used the search terms: bisphenol AND (decidua OR placenta OR myometrium OR amnion OR chorion OR trophoblast) in the ScienceDirect database. The search was performed last August 2021.

\subsection{Inclusion Criteria}

Since this is an integrative approach towards possible mechanisms of bisphenols contributing towards preterm birth, we included studies that would utilize bisphenol exposure on human or animal placental samples/animal models/tissue explants/in vitro cell cultures. We considered accessible, full-text articles that have been published in English or translated to English from 1999 to 2021.

\subsection{Exclusion Criteria}

We excluded articles that were individually assessed to be not related to mechanisms of preterm birth or parturition, as well as duplicate articles and review articles.

\subsection{Article Strength Determination}

We followed evidence determination similar to Peretz et al., 2014 [123]. Evidence was considered strong if multiple studies across different species indicate similar effect or outcome in a specific reproductive tissue, despite not $100 \%$ concordance to allow for species and strain differences. Evidence was considered limited when some studies, but not predominantly, indicate similar effect or outcome, or when discordant data is available across all studies. Lastly, evidence was considered inconclusive if only limited studies were performed in only one species or via in vitro studies alone.

Author Contributions: Conceptualization and draft writing-M.S.V.J.; Review and editing-R.M., G.F.B.Y. and M.D.A. All authors have read and agreed to the published version of the manuscript.

Funding: The APC was funded by the College of Medicine, University of the Philippines Manila; the MD-PhD in Molecular Medicine Committee of the College of Medicine, University of the Phil-ippines Manila; and the Department of Science and Technology-Philippine Council for Health Research and Development (DOST-PCHRD), Philippines.

Institutional Review Board Statement: Not applicable.

Informed Consent Statement: Not applicable.

Data Availability Statement: Not applicable.

Acknowledgments: M.S.V.J. would like to thank Enrico Paolo C. Banzuela, MSEd, MHPEd, FPSP for his kind assistance.

Conflicts of Interest: The authors declare no conflict of interest.

\section{References}

1. Preterm Birth. 19 February 2018. Available online: https://www.who.int/news-room/fact-sheets/detail/preterm-birth (accessed on 14 March 2021).

2. Blencowe, H.; Cousens, S.; Chou, D.; Oestergaard, M.; Say, L.; Moller, A.-B.; Kinney, M.; Lawn, J.; the Born Too Soon Preterm Birth Action Group. Born Too Soon: The global epidemiology of 15 million preterm births. Reprod. Health 2013, 10 (Suppl. S1), S2. [CrossRef] [PubMed]

3. Saigal, S.; Doyle, L. An overview of mortality and sequelae of preterm birth from infancy to adulthood. Lancet 2008, 371, 261-269. [CrossRef] 
4. Menon, R. Spontaneous preterm birth, a clinical dilemma: Etiologic, pathophysiologic and genetic heterogeneities and racial disparity. Acta Obstet. Gynecol. Scand. 2008, 87, 590-600. [CrossRef] [PubMed]

5. Goldenberg, R.L.; Culhane, J.F.; Iams, J.D.; Romero, R. Epidemiology and causes of preterm birth. Lancet 2008, 371, 75-84. [CrossRef]

6. Institute of Medicine (US) Committee on Understanding Premature Birth and Assuring Healthy Outcomes; Behrman, R.E.; Butler, A.S. (Eds.) The Role of Environmental Toxicants in Preterm Birth. In Preterm Birth: Causes, Consequences, and Prevention; National Academies Press: Washington, DC, USA, 2007. Available online: https://www.ncbi.nlm.nih.gov/books/NBK11368/ (accessed on 1 August 2021).

7. Porpora, M.G.; Piacenti, I.; Scaramuzzino, S.; Masciullo, L.; Rech, F.; Panici, P.B. Environmental Contaminants Exposure and Preterm Birth: A Systematic Review. Toxics 2019, 7, 11. [CrossRef] [PubMed]

8. Huang, S.; Li, J.; Xu, S.; Zhao, H.; Li, Y.; Zhou, Y.; Fang, J.; Liao, J.; Cai, Z.; Xia, W. Bisphenol A and bisphenol S exposures during pregnancy and gestational age-A longitudinal study in China. Chemosphere 2019, 237, 124426. [CrossRef]

9. Mustieles, V.; Zhang, Y.; Yland, J.; Braun, J.M.; Williams, P.L.; Wylie, B.J.; Attaman, J.A.; Ford, J.B.; Azevedo, A.; Calafat, A.M.; et al. Maternal and paternal preconception exposure to phenols and preterm birth. Environ. Int. 2020, 137, 105523. [CrossRef]

10. Cantonwine, D.; Meeker, J.D.; Hu, H.; Sánchez, B.N.; Lamadrid-Figueroa, H.; Mercado-García, A.; Fortenberry, G.Z.; Calafat, A.M.; Téllez-Rojo, M.M. Bisphenol a exposure in Mexico City and risk of prematurity: A pilot nested case control study. Environ. Health 2010, 9, 62. [CrossRef]

11. Aung, M.T.; Ferguson, K.; Cantonwine, D.E.; McElrath, T.F.; Meeker, J.D. Preterm birth in relation to the bisphenol A replacement, bisphenol S, and other phenols and parabens. Environ. Res. 2018, 169, 131-138. [CrossRef]

12. Vandenberg, L.N.; Hauser, R.; Marcus, M.; Olea, N.; Welshons, W.V. Human exposure to bisphenol A (BPA). Reprod. Toxicol. 2007, 24, 139-177. [CrossRef]

13. Staples, C.A.; Dome, P.B.; Klecka, G.M.; Oblock, S.T.; Harris, L.R. A review of the environmental fate, effects, and exposures of bisphenol A. Chemosphere 1998, 36, 2149-2173. [CrossRef]

14. Vom Saal, F.S.; Hughes, C. An Extensive New Literature Concerning Low-Dose Effects of Bisphenol A Shows the Need for a New Risk Assessment. Environ. Health Perspect. 2005, 113, 926-933. [CrossRef] [PubMed]

15. Clark, E. Sulfolane and sulfones. In Kirk-Othmer Encyclopedia of Chemical Technology; Wiley: New York, NY, USA, 2000.

16. Liao, C.; Kannan, K. Concentrations and Profiles of Bisphenol A and Other Bisphenol Analogues in Foodstuffs from the United States and Their Implications for Human Exposure. J. Agric. Food Chem. 2013, 61, 4655-4662. [CrossRef] [PubMed]

17. Liao, C.; Liu, F.; Kannan, K. Bisphenol S, a New Bisphenol Analogue, in Paper Products and Currency Bills and Its Association with Bisphenol A Residues. Environ. Sci. Technol. 2012, 46, 6515-6522. [CrossRef]

18. Liao, C.; Kannan, K. A Survey of Alkylphenols, Bisphenols, and Triclosan in Personal Care Products from China and the United States. Arch. Environ. Contam. Toxicol. 2014, 67, 50-59. [CrossRef]

19. Namat, A.; Xia, W.; Xiong, C.; Xu, S.; Wu, C.; Wang, A.; Li, Y.; Wu, Y.; Li, J. Association of BPA exposure during pregnancy with risk of preterm birth and changes in gestational age: A meta-analysis and systematic review. Ecotoxicol. Environ. Saf. 2021, 220, 112400. [CrossRef]

20. Bukovsky, A.; Caudle, M.R.; Cekanova, M.; Fernando, R.I.; Wimalasena, J.; Foster, J.S.; Henley, D.C.; Elder, R.F. Placental expression of estrogen receptor beta and its hormone binding variant-Comparison with estrogen receptor alpha and a role for estrogen receptors in asymmetric division and differentiation of estrogen-dependent cells. Reprod. Biol. Endocrinol. 2003, 1, 36. [CrossRef]

21. De Aguiar Greca, S.-C.; Kyrou, I.; Pink, R.; Randeva, H.; Grammatopoulos, D.; Silva, E.; Karteris, E. Effects of the Endocrine Disrupting Chemical Bisphenol A (Bpa) in Human Placentation in vitro. EJEA. Available online: http:/ / www.endocrine-abstracts. org/ea/0065/ea0065p358.htm (accessed on 19 July 2021).

22. Morice, L.; Benaîtreau, D.; Dieudonné, M.-N.; Morvan, C.; Serazin, V.; de Mazancourt, P.; Pecquery, R.; Dos Santos, E. Antiproliferative and proapoptotic effects of bisphenol A on human trophoblastic JEG-3 cells. Reprod. Toxicol. 2011, 32, 69-76. [CrossRef]

23. Profita, M.; Fabbri, E.; Spisni, E.; Valbonesi, P. Comparing effects and action mechanisms of BPA and BPS on HTR-8/Svneo placental cells. Biol. Reprod. 2021, 105, 1355-1364. [CrossRef]

24. Spagnoletti, A.; Paulesu, L.; Mannelli, C.; Ermini, L.; Romagnoli, R.; Cintorino, M.; Ietta, F. Low concentrations of Bisphenol A and para-Nonylphenol affect extravillous pathway of human trophoblast cells. Mol. Cell. Endocrinol. 2015, 412, 56-64. [CrossRef]

25. Benachour, N.; Aris, A. Toxic effects of low doses of Bisphenol-A on human placental cells. Toxicol. Appl. Pharmacol. 2009, 241, 322-328. [CrossRef] [PubMed]

26. Wang, Z.-Y.; Lu, J.; Zhang, Y.-Z.; Zhang, M.; Liu, T.; Qu, X.-L. Effect of Bisphenol A on invasion ability of human trophoblastic cell line BeWo. Int. J. Clin. Exp. Pathol. 2015, 8, 14355-14364. [PubMed]

27. Mørck, T.J.; Sorda, G.; Bechi, N.; Rasmussen, B.S.; Nielsen, J.B.; Ietta, F.; Rytting, E.; Mathiesen, L.; Paulesu, L.; Knudsen, L.E. Placental transport and in vitro effects of Bisphenol A. Reprod. Toxicol. 2010, 30, 131-137. [CrossRef] [PubMed]

28. Chu, P.-W.; Yang, Z.-J.; Huang, H.-S.; Chang, A.-A.; Cheng, Y.-C.; Wu, G.-J.; Lan, H.-C. Low-dose bisphenol A activates the ERK signaling pathway and attenuates steroidogenic gene expression in human placental cells. Biol. Reprod. 2017, 98, 250-258. [CrossRef] 
29. Pérez-Albaladejo, E.; Fernandes, D.; Lacorte, S.; Porte, C. Comparative toxicity, oxidative stress and endocrine disruption potential of plasticizers in JEG-3 human placental cells. Toxicol. In Vitro 2017, 38, 41-48. [CrossRef]

30. Takeda, Y.; Liu, X.; Sumiyoshi, M.; Matsushima, A.; Shimohigashi, M.; Shimohigashi, Y. Placenta expressing the greatest quantity of bisphenol A receptor ERR \{gamma\} among the human reproductive tissues: Predominant expression of type-1 ERRgamma isoform. J. Biochem. 2009, 146, 113-122. [CrossRef]

31. Avissar-Whiting, M.; Veiga, K.R.; Uhl, K.M.; Maccani, M.A.; Gagne, L.A.; Moen, E.L.; Marsit, C.J. Bisphenol A exposure leads to specific microRNA alterations in placental cells. Reprod. Toxicol. 2010, 29, 401-406. [CrossRef]

32. De Felice, B.; Manfellotto, F.; Palumbo, A.R.; Troisi, J.; Zullo, F.; Di Carlo, C.; Sardo, A.D.S.; De Stefano, N.; Ferbo, U.; Guida, M.; et al. Genome-wide microRNA expression profiling in placentas from pregnant women exposed to BPA. BMC Med. Genom. 2015, 8, 56. [CrossRef]

33. Narciso, L.; Ietta, F.; Romagnoli, R.; Paulesu, L.; Mantovani, A.; Tait, S. Effects of Bisphenol A on endogenous retroviral envelopes expression and trophoblast fusion in BeWo cells. Reprod. Toxicol. 2019, 89, 35-44. [CrossRef]

34. Mao, J.; Jain, A.; Denslow, N.D.; Nouri, M.-Z.; Chen, S.; Wang, T.; Zhu, N.; Koh, J.; Sarma, S.J.; Sumner, B.W.; et al. Bisphenol A and bisphenol $\mathrm{S}$ disruptions of the mouse placenta and potential effects on the placenta-brain axis. Proc. Natl. Acad. Sci. USA 2020, 117, 4642-4652. [CrossRef]

35. Lan, X.; Fu, L.-J.; Zhang, J.; Liu, X.-Q.; Zhang, H.-J.; Zhang, X.; Ma, M.-F.; Chen, X.-M.; He, J.-L.; Li, L.-B.; et al. Bisphenol A exposure promotes HTR-8/Svneo cell migration and impairs mouse placentation involving upregulation of integrin- $\beta 1$ and MMP-9 and stimulation of MAPK and PI3K signaling pathways. Oncotarget 2017, 8, 51507-51521. [CrossRef] [PubMed]

36. Tachibana, T.; Wakimoto, Y.; Nakamuta, N.; Phichitraslip, T.; Wakitani, S.; Kusakabe, K.; Hondo, E.; Kiso, Y. Effects of Bisphenol A (BPA) on Placentation and Survival of the Neonates in Mice. J. Reprod. Dev. 2007, 53, 509-514. [CrossRef] [PubMed]

37. Tait, S.; Tassinari, R.; Maranghi, F.; Mantovani, A. Bisphenol A affects placental layers morphology and angiogenesis during early pregnancy phase in mice: BPA exposure affects placenta angiogenesis. J. Appl. Toxicol. 2015, 35, 1278-1291. [CrossRef] [PubMed]

38. Gao, J.; Song, T.; Che, D.; Li, C.; Jiang, J.; Pang, J.; Yang, Y.; Goma; Li, P. The effect of bisphenol a exposure onto endothelial and decidualized stromal cells on regulation of the invasion ability of trophoblastic spheroids in in vitro co-culture model. Biochem. Biophys. Res. Commun. 2019, 516, 506-514. [CrossRef]

39. Wei, P.; Ru, D.; Li, X.; Shi, D.; Zhang, M.; Xu, Q.; Zhou, H.; Wen, S. Exposure to environmental bisphenol A inhibits HTR-8/Svneo cell migration and invasion. J. Biomed. Res. 2020, 34, 369-378. [CrossRef]

40. Barberio, L.; Paulesu, L.; Canesi, L.; Grasselli, E.; Mandalà, M. Bisphenol a Interferes with Uterine Artery Features and Impairs Rat Feto-Placental Growth. Int. J. Mol. Sci. 2021, 22, 6912. [CrossRef]

41. Müller, J.E.; Meyer, N.; Santamaria, C.G.; Schumacher, A.; Luque, E.H.; Zenclussen, M.L.; Rodriguez, H.A.; Zenclussen, A.C. Bisphenol A exposure during early pregnancy impairs uterine spiral artery remodeling and provokes intrauterine growth restriction in mice. Sci. Rep. 2018, 8, 9196. [CrossRef]

42. Basak, S.; Srinivas, V.; Duttaroy, A.K. Bisphenol-A impairs cellular function and alters DNA methylation of stress pathway genes in first trimester trophoblast cells. Reprod. Toxicol. 2018, 82, 72-79. [CrossRef]

43. Gwon, L.W.; Park, S.G.; Lin, C.; Lee, B.J.; Nam, S.-Y. The effects of caffeine and bisphenol A singularly or in combination on cultured mouse embryos and yolk sac placenta. Reprod. Toxicol. 2019, 91, 92-100. [CrossRef]

44. Xu, H.; Zhang, X.; Ye, Y.; Li, X. Bisphenol A affects estradiol metabolism by targeting CYP1A1 and CYP19A1 in human placental JEG-3 cells. Toxicol. In Vitro 2019, 61, 104615. [CrossRef]

45. Huang, H.; Leung, L.K. Bisphenol A downregulates CYP19 transcription in JEG-3 cells. Toxicol. Lett. 2009, 189, 248-252. [CrossRef] [PubMed]

46. Nativelle-Serpentini, C.; Richard, S.; Séralini, G.-E.; Sourdaine, P. Aromatase activity modulation by lindane and bisphenol-A in human placental JEG-3 and transfected kidney E293 cells. Toxicol. In Vitro 2003, 17, 413-422. [CrossRef]

47. Benachour, N.; Moslemi, S.; Sipahutar, H.; Seralini, G. Cytotoxic effects and aromatase inhibition by xenobiotic endocrine disrupters alone and in combination. Toxicol. Appl. Pharmacol. 2007, 222, 129-140. [CrossRef] [PubMed]

48. Xiao, S.; Diao, H.; Smith, M.A.; Song, X.; Ye, X. Preimplantation exposure to bisphenol A (BPA) affects embryo transport, preimplantation embryo development, and uterine receptivity in mice. Reprod. Toxicol. 2011, 32, 434-441. [CrossRef]

49. Park, C.; Song, H.; Choi, J.; Sim, S.; Kojima, H.; Park, J.; Iida, M.; Lee, Y. The mixture effects of bisphenol derivatives on estrogen receptor and androgen receptor. Environ. Pollut. 2020, 260, 114036. [CrossRef]

50. Imanishi, S.; Manabe, N.; Nishizawa, H.; Morita, M.; Sugimoto, M.; Iwahori, M.; Miyamoto, H. Effects of Oral Exposure of Bisphenol A on mRNA Expression of Nuclear Receptors in Murine Placentae Assessed by DNA Microarray. J. Reprod. Dev. 2003, 49, 329-336. [CrossRef]

51. Tong, C.; Feng, X.; Chen, J.; Qi, X.; Zhou, L.; Shi, S.; Kc, K.; Stanley, J.L.; Baker, P.N.; Zhang, H. G protein-coupled receptor 30 regulates trophoblast invasion and its deficiency is associated with preeclampsia. J. Hypertens. 2016, 34, 710-718. [CrossRef]

52. Greca, S.-C.D.A.; Kyrou, I.; Pink, R.; Randeva, H.; Grammatopoulos, D.; Silva, E.; Karteris, E. Involvement of the EndocrineDisrupting Chemical Bisphenol A (BPA) in Human Placentation. J. Clin. Med. 2020, 9, 405. [CrossRef]

53. Okamoto, E.; Takagi, T.; Azuma, C.; Kimura, T.; Tokugawa, Y.; Mitsuda, N.; Saji, F.; Tanizawa, O. Expression of the CorticotropinReleasing Hormone (CRH) Gene in Human Placenta and Amniotic Membrane. Horm. Metab. Res. 1990, 22, 394-397. [CrossRef]

54. Challis, J.R.G. CRH, a placental clock and preterm labour. Nat. Med. 1995, 1, 416. [CrossRef] 
55. Huang, H.; Tan, W.; Wang, C.; Leung, L.K. Bisphenol A induces corticotropin-releasing hormone expression in the placental cells JEG-3. Reprod. Toxicol. 2012, 34, 317-322. [CrossRef] [PubMed]

56. Tan, W.; Huang, H.; Wang, Y.; Wong, T.Y.; Wang, C.; Leung, L.K. Bisphenol A differentially activates protein kinase C isoforms in murine placental tissue. Toxicol. Appl. Pharmacol. 2013, 269, 163-168. [CrossRef] [PubMed]

57. You, X.; Yang, R.; Tang, X.; Gao, L.; Ni, X. Corticotropin-Releasing Hormone Stimulates Estrogen Biosynthesis in Cultured Human Placental Trophoblasts1. Biol. Reprod. 2006, 74, 1067-1072. [CrossRef] [PubMed]

58. Yang, R.; You, X.; Tang, X.; Gao, L.; Ni, X. Corticotropin-releasing hormone inhibits progesterone production in cultured human placental trophoblasts. J. Mol. Endocrinol. 2006, 37, 533-540. [CrossRef] [PubMed]

59. Arita, Y.; Park, H.J.; Cantillon, A.; Getahun, D.; Menon, R.; Peltier, M.R. Effect of bisphenol-A (BPA) on placental biomarkers for inflammation, neurodevelopment and oxidative stress. J. Périnat. Med. 2019, 47, 741-749. [CrossRef]

60. Song, W.; Puttabyatappa, M.; Zeng, L.; Vazquez, D.; Pennathur, S.; Padmanabhan, V. Developmental programming: Prenatal bisphenol A treatment disrupts mediators of placental function in sheep. Chemosphere 2019, 243, 125301. [CrossRef]

61. Kallapur, S.G.; Presicce, P.; Senthamaraikannan, P.; Alvarez, M.; Tarantal, A.F.; Miller, L.M.; Jobe, A.H.; Chougnet, C.A. IntraAmniotic IL-1 $\beta$ Induces Fetal Inflammation in Rhesus Monkeys and Alters the Regulatory T Cell/IL-17 Balance. J. Immunol. 2013, 191, 1102-1109. [CrossRef] [PubMed]

62. Sadowsky, D.W.; Adams, K.M.; Gravett, M.G.; Witkin, S.S.; Novy, M.J. Preterm labor is induced by intraamniotic infusions of interleukin- $1 \beta$ and tumor necrosis factor- $\alpha$ but not by interleukin- 6 or interleukin- 8 in a nonhuman primate model. Am. J. Obstet. Gynecol. 2006, 195, 1578-1589. [CrossRef]

63. Wakabayashi, A.; Sawada, K.; Nakayama, M.; Toda, A.; Kimoto, A.; Mabuchi, S.; Kinose, Y.; Nakamura, K.; Takahashi, K.; Kurachi, H.; et al. Targeting interleukin-6 receptor inhibits preterm delivery induced by inflammation. Mol. Hum. Reprod. 2013, 19, 718-726. [CrossRef]

64. Ponniah, M.; Billett, E.E.; De Girolamo, L.A. Bisphenol A Increases BeWo Trophoblast Survival in Stress-Induced Paradigms through Regulation of Oxidative Stress and Apoptosis. Chem. Res. Toxicol. 2015, 28, 1693-1703. [CrossRef]

65. Sheller-Miller, S.; Radnaa, E.; Arita, Y.; Getahun, D.; Jones, R.J.; Peltier, M.R.; Menon, R. Environmental pollutant induced cellular injury is reflected in exosomes from placental explants. Placenta 2020, 89, 42-49. [CrossRef] [PubMed]

66. Menon, R.; Sheller, S.; Saade, G.; Salomon, C. Oxidative stress induced amnion cell derived exosomes produce inflammatory changes in myometrial cells: A feto-maternal signaling in human parturition. Placenta 2016, 45, 111-112. [CrossRef]

67. Marinić, M.; Mika, K.; Chigurupati, S.; Lynch, V.J. Evolutionary transcriptomics implicates HAND2 in the origins of implantation and regulation of gestation length. eLife 2021, 10, e61257. [CrossRef]

68. Brighton, P.J.; Maruyama, Y.; Fishwick, K.; Vrljicak, P.; Tewary, S.; Fujihara, R.; Muter, J.; Lucas, E.S.; Yamada, T.; Woods, L.; et al. Clearance of senescent decidual cells by uterine natural killer cells in cycling human endometrium. eLife 2017, 6, e31274. [CrossRef]

69. Cha, J.M.; Aronoff, D.M. A role for cellular senescence in birth timing. Cell Cycle 2017, 16, 2023-2031. [CrossRef]

70. Cho, Y.J.; Park, S.B.; Park, J.W.; Oh, S.R.; Han, M. Bisphenol A modulates inflammation and proliferation pathway in human endometrial stromal cells by inducing oxidative stress. Reprod. Toxicol. 2018, 81, 41-49. [CrossRef]

71. Sarno, J.L.; Schatz, F.; Lockwood, C.J.; Huang, S.-T.J.; Taylor, H.S. Thrombin and Interleukin-1ß Regulate HOXA10 Expression in Human Term Decidual Cells: Implications for Preterm Labor. J. Clin. Endocrinol. Metab. 2006, 91, 2366-2372. [CrossRef]

72. Oner, C.; Schatz, F.; Kizilay, G.; Murk, W.; Buchwalder, L.F.; Kayisli, U.A.; Arici, A.; Lockwood, C.J. Progestin-Inflammatory Cytokine Interactions Affect Matrix Metalloproteinase-1 and -3 Expression in Term Decidual Cells: Implications for Treatment of Chorioamnionitis-Induced Preterm Delivery. J. Clin. Endocrinol. Metab. 2008, 93, 252-259. [CrossRef]

73. Lockwood, C.J.; Murk, W.K.; Kayisli, U.A.; Buchwalder, L.F.; Huang, S.J.; Arcuri, F.; Li, M.; Gopinath, A.; Schatz, F. Regulation of Interleukin-6 Expression in Human Decidual Cells and Its Potential Role in Chorioamnionitis. Am. J. Pathol. 2010, 177, 1755-1764. [CrossRef]

74. Mannelli, C.; Szóstek, A.Z.; Lukasik, K.; Carotenuto, C.; Ietta, F.; Romagnoli, R.; Ferretti, C.; Paulesu, L.; Wołczynski, S.; Skarzynski, D.J. Bisphenol A modulates receptivity and secretory function of human decidual cells: An in vitro study. Reproduction 2015, 150, 115-125. [CrossRef]

75. Aghajanova, L.; Giudice, L.C. Effect of bisphenol A on human endometrial stromal fibroblasts in vitro. Reprod. BioMed. Online 2011, 22, 249-256. [CrossRef]

76. Berger, R.G.; Foster, W.G.; Decatanzaro, D. Bisphenol-A exposure during the period of blastocyst implantation alters uterine morphology and perturbs measures of estrogen and progesterone receptor expression in mice. Reprod. Toxicol. 2010, 30, 393-400. [CrossRef]

77. Aldad, T.S.; Rahmani, N.; Leranth, C.; Taylor, H.S. Bisphenol-A exposure alters endometrial progesterone receptor expression in the nonhuman primate. Fertil. Steril. 2011, 96, 175-179. [CrossRef]

78. Varayoud, J.; Ramos, J.G.; Bosquiazzo, V.L.; Muñoz-De-Toro, M.; Luque, E.H. Developmental Exposure to Bisphenol A Impairs the Uterine Response to Ovarian Steroids in the Adult. Endocrinology 2008, 149, 5848-5860. [CrossRef]

79. Xiong, Y.; Wen, X.; Liu, H.; Zhang, M.; Zhang, Y. Bisphenol a affects endometrial stromal cells decidualization, involvement of epigenetic regulation. J. Steroid Biochem. Mol. Biol. 2020, 200, 105640. [CrossRef]

80. Matsumoto, H.; Sakai, K.; Iwashita, M. Insulin-like growth factor binding protein-1 induces decidualization of human endometrial stromal cells via 51 integrin. Mol. Hum. Reprod. 2008, 14, 485-489. [CrossRef] 
81. Rhee, H.S.; Oh, S.H.; Ko, B.J.; Han, D.M.; Jeon, B.H.; Park, H.; Moon, H.B.; Kim, W.S. Expression of 3b-Hydroxysteroid dehydrogenase and P450 side chain cleavage enzyme in the human uterine endometrium. Exp. Mol. Med. 2003, 35, 160-166. [CrossRef]

82. Forte, M.; Mita, L.; Cobellis, L.; Merafina, V.; Specchio, R.; Rossi, S.; Mita, D.G.; Mosca, L.; Castaldi, M.A.; De Falco, M.; et al. Triclosan and bisphenol a affect decidualization of human endometrial stromal cells. Mol. Cell. Endocrinol. 2016, 422, 74-83. [CrossRef]

83. Koyama-Nasu, R.; Nasu-Nishimura, Y.; Todo, T.; Ino, Y.; Saito, N.; Aburatani, H.; Funato, K.; Echizen, K.; Sugano, H.; Haruta, R.; et al. The critical role of cyclin D2 in cell cycle progression and tumorigenicity of glioblastoma stem cells. Oncogene 2012, 32, 3840-3845. [CrossRef]

84. Olson, M.R.; Su, R.; Flaws, J.; Fazleabas, A.T. Bisphenol A impairs decidualization of human uterine stromal fibroblasts. Reprod. Toxicol. 2017, 73, 339-344. [CrossRef]

85. Yuan, M.; Hu, M.; Lou, Y.; Wang, Q.; Mao, L.; Zhan, Q.; Jin, F. Environmentally relevant levels of bisphenol A affect uterine decidualization and embryo implantation through the estrogen receptor/serum and glucocorticoid-regulated kinase 1/epithelial sodium ion channel $\alpha$-subunit pathway in a mouse model. Fertil. Steril. 2018, 109, 735-744.e1. [CrossRef] [PubMed]

86. Fan, H.; Jiang, L.; Lee, Y.-L.; Wong, C.K.C.; Ng, E.H.Y.; Yeung, W.S.B.; Lee, K.-F. Bisphenol compounds regulate decidualized stromal cells in modulating trophoblastic spheroid outgrowth and invasion in vitrot. Biol. Reprod. 2019, 102, 693-704. [CrossRef] [PubMed]

87. Kim, H.-R.; Kim, Y.S.; Yoon, J.A.; Lyu, S.W.; Shin, H.; Lim, H.J.; Hong, S.-H.; Lee, D.R.; Song, H. Egr1 is rapidly and transiently induced by estrogen and bisphenol A via activation of nuclear estrogen receptor-dependent ERK1/2 pathway in the uterus. Reprod. Toxicol. 2014, 50, 60-67. [CrossRef]

88. Guo, B.; Tian, X.-C.; Li, D.-D.; Yang, Z.-Q.; Cao, H.; Zhang, Q.-L.; Liu, J.-X.; Yue, Z.-P. Expression, regulation and function of Egr1 during implantation and decidualization in mice. Cell Cycle 2014, 13, 2626-2640. [CrossRef]

89. Enquobahrie, D.A.; Williams, M.A.; Qiu, C.; Muhie, S.Y.; Slentz-Kesler, K.; Ge, Z.; Sorenson, T. Early pregnancy peripheral blood gene expression and risk of preterm delivery: A nested case control study. BMC Pregnancy Childbirth 2009, 9, 56. [CrossRef]

90. Shin, S.Y.; Kim, J.H.; Baker, A.; Lim, Y.; Lee, Y.H. Transcription Factor Egr-1 Is Essential for Maximal Matrix Metalloproteinase-9 Transcription by Tumor Necrosis Factor $\alpha$. Mol. Cancer Res. 2010, 8, 507-519. [CrossRef]

91. Godbole, G.; Suman, P.; Malik, A.; Galvankar, M.; Joshi, N.; Fazleabas, A.; Gupta, S.K.; Modi, D. Decrease in Expression of HOXA10 in the Decidua After Embryo Implantation Promotes Trophoblast Invasion. Endocrinology 2017, 158, $2618-2633$. [CrossRef]

92. Li, X.; Wang, Y.; Wei, P.; Shi, D.; Wen, S.; Wu, F.; Liu, L.; Ye, N.; Zhou, H. Bisphenol A affects trophoblast invasion by inhibiting CXCL8 expression in decidual stromal cells. Mol. Cell. Endocrinol. 2017, 470, 38-47. [CrossRef]

93. Okuda, K.; Takiguchi, M.; Yoshihara, S. In vivo estrogenic potential of 4-methyl-2,4-bis(4-hydroxyphenyl)pent-1-ene, an active metabolite of bisphenol A, in uterus of ovariectomized rat. Toxicol. Lett. 2010, 197, 7-11. [CrossRef]

94. Cook, J.C.; Kaplan, A.M.; Davis, L.G.; O'Connor, J.C. Development of a Tier I Screening Battery for Detecting Endocrine-Active Compounds (EACs). Regul. Toxicol. Pharmacol. 1997, 26 Pt 1, 60-68. [CrossRef]

95. Gray, L.E., Jr.; Ostby, J. Effects of Pesticides and Toxic Substances On Behavioral and Morphological Reproductive Development: Endocrine Versus Nonendocrine Mechanisms. Toxicol. Ind. Health 1998, 14, 159-184.

96. Dodge, J.A.; Glasebrook, A.L.; Magee, D.E.; Phillips, D.L.; Sato, M.; Short, L.L.; Bryant, H.U. Environmental estrogens: Effects on cholesterol lowering and bone in the ovariectomized rat. J. Steroid Biochem. Mol. Biol. 1996, 59, 155-161. [CrossRef]

97. Ashby, J.; Tinwell, H. Uterotrophic activity of bisphenol A in the immature rat. Environ. Health Perspect. 1998, 106, 719-720. [CrossRef] [PubMed]

98. Morrison, A.; Callanan, J.; Evans, N.; Aldridge, T.; Sweeney, T. Effects of endocrine disrupting compounds on the pathology and oestrogen receptor $\alpha$ and $\beta$ distribution in the uterus and cervix of ewe lambs. Domest. Anim. Endocrinol. 2003, 25, 329-343. [CrossRef] [PubMed]

99. Othman, E.R.; Al-Adly, D.M.M.; Elgamal, D.A.; Ghandour, N.; El-Sharkawy, S. Bisphenol A Concentrates Preferentially in Human Uterine Leiomyoma and Induces Proliferation in Rat Myometrium. Reprod. Sci. 2016, 23, 508-514. [CrossRef]

100. Papaconstantinou, A.D.; Umbreit, T.H.; Fisher, B.R.; Goering, P.L.; Lappas, N.T.; Brown, K.M. Bisphenol A-Induced Increase in Uterine Weight and Alterations in Uterine Morphology in Ovariectomized B6C3F1 Mice: Role of the Estrogen Receptor. Toxicol. Sci. 2000, 56, 332-339. [CrossRef]

101. Papaconstantinou, A.D.; Fisher, B.R.; Umbreit, T.H.; Goering, P.L.; Lappas, N.T.; Brown, K.M. Effects of beta-estradiol and bisphenol A on heat shock protein levels and localization in the mouse uterus are antagonized by the antiestrogen ICI 182,780. Toxicol. Sci. 2001, 63, 173-180. [CrossRef]

102. An, B.-S.; Ahn, H.-J.; Kang, H.-S.; Jung, E.-M.; Yang, H.; Hong, E.-J.; Jeung, E.-B. Effects of estrogen and estrogenic compounds, 4-tert-octylphenol, and bisphenol A on the uterine contraction and contraction-associated proteins in rats. Mol. Cell. Endocrinol. 2013, 375, 27-34. [CrossRef]

103. Salleh, N.; Giribabu, N.; Feng, A.O.M.; Myint, K. Bisphenol A, Dichlorodiphenyltrichloroethane (DDT) and Vinclozolin Affect ex-vivo Uterine Contraction in Rats via Uterotonin (Prostaglandin F2 $\alpha$, Acetylcholine and Oxytocin) Related Pathways. Int. J. Med. Sci. 2015, 12, 914-925. [CrossRef] 
104. Gupta, H.; Deshpande, S.B. Bisphenol A decreases the spontaneous contractions of rat uterus in vitro through a nitrergic mechanism. J. Basic Clin. Physiol. Pharmacol. 2018, 29, 593-598. [CrossRef]

105. Liliana, R.; Slawomir, G.; Tomasz, J.; Joanna, W.; Andrzej, P. The Neurochemical Characterization of Parasympathetic Nerve Fibers in the Porcine Uterine Wall Under Physiological Conditions and After Exposure to Bisphenol A (BPA). Neurotox. Res. 2019, 35, 867-882. [CrossRef] [PubMed]

106. Liliana, R.; Slawomir, G.; Tomasz, J.; Joanna, W.; Andrzej, P. The effects of Bisphenol A (BPA) on sympathetic nerve fibers in the uterine wall of the domestic pig. Reprod. Toxicol. 2018, 84, 39-48. [CrossRef] [PubMed]

107. Maiti, K.; Paul, J.; Read, M.; Chan, E.C.; Riley, S.; Nahar, P.; Smith, R. G-1-Activated Membrane Estrogen Receptors Mediate Increased Contractility of the Human Myometrium. Endocrinology 2011, 152, 2448-2455. [CrossRef] [PubMed]

108. Kita, K.; Jin, Y.-H.; Sun, Z.; Chen, S.-P.; Sumiya, Y.; Hongo, T.; Suzuki, N. Increase in the levels of chaperone proteins by exposure to $\beta$-estradiol, bisphenol A and 4-methoxyphenol in human cells transfected with estrogen receptor $\alpha$ cDNA. Toxicol. Vitr. 2009, 23, 728-735. [CrossRef]

109. Kang, S.Y.; Kim, M.-R.; Kim, J.H.; Cho, H.H. Gene expression profiles of the normal myometrium after 48 and 96 hours of exposure to BPA. BioChip J. 2015, 9, 293-299. [CrossRef]

110. Kang, S.Y.; Song, J.Y.; Cho, H.H. Gene expression analysis of uterine smooth muscle cells exposed to bisphenol A. Toxicol. Environ. Health Sci. 2014, 6, 261-267. [CrossRef]

111. Li, Y.; Li, H.; Xie, N.; Chen, R.; Lee, A.R.; Slater, D.; Lye, S.; Dong, X. HoxA10 and HoxA11 Regulate the Expression of Contraction-Associated Proteins and Contribute to Regionalized Myometrium Phenotypes in Women. Reprod. Sci. 2017, 25, 44-50. [CrossRef]

112. Cermik, D.; Karaca, M.; Taylor, H.S. HOXA10 Expression Is Repressed by Progesterone in the Myometrium: Differential Tissue-Specific Regulation of HOX Gene Expression in the Reproductive Tract1. J. Clin. Endocrinol. Metab. 2001, 86, $3387-3392$.

113. Edlow, A.G.; Chen, M.; Smith, N.A.; Lu, C.; McElrath, T.F. Fetal bisphenol A exposure: Concentration of conjugated and unconjugated bisphenol A in amniotic fluid in the second and third trimesters. Reprod. Toxicol. 2012, 34, 1-7. [CrossRef]

114. Sheller-Miller, S.; Papaconstantinou, J.; Urrabaz-Garza, R.; Richardson, L.; Saade, G.; Salomon, C.; Menon, R. Amnion-EpithelialCell-Derived Exosomes Demonstrate Physiologic State of Cell under Oxidative Stress. PLoS ONE 2016, 11, e0157614.

115. Menon, R.; Papaconstantinou, J. p38 Mitogen activated protein kinase (MAPK): A new therapeutic target for reducing the risk of adverse pregnancy outcomes. Expert Opin. Ther. Targets 2016, 20, 1397-1412. [CrossRef] [PubMed]

116. Menon, R.; Boldogh, I.; Urrabaz-Garza, R.; Polettini, J.; Syed, T.A.; Saade, G.R.; Papaconstantinou, J.; Taylor, R.N. Senescence of Primary Amniotic Cells via Oxidative DNA Damage. PLoS ONE 2013, 8, e83416. [CrossRef] [PubMed]

117. Omere, C.; Richardson, L.; Saade, G.R.; Bonney, E.A.; Kechichian, T.; Menon, R. Interleukin (IL)-6: A Friend or Foe of Pregnancy and Parturition? Evidence From Functional Studies in Fetal Membrane Cells. Front. Physiol. 2020, 11, 891. [CrossRef] [PubMed]

118. Mitchell, M.D.; Dudley, D.J.; Edwin, S.S.; Schiller, S.L. Interleukin-6 stimulates prostaglandin production by human amnion and decidual cells. Eur. J. Pharmacol. 1991, 192, 189-191. [CrossRef]

119. Gingrich, J.; Pu, Y.; Roberts, J.; Karthikraj, R.; Kannan, K.; Ehrhardt, R.; Veiga-Lopez, A. Gestational bisphenol S impairs placental endocrine function and the fusogenic trophoblast signaling pathway. Arch. Toxicol. 2018, 92, 1861-1876. [CrossRef] [PubMed]

120. Ticiani, E.; Gingrich, J.; Pu, Y.; Vettathu, M.; Davis, J.; Martin, D.; Petroff, M.G.; Veiga-Lopez, A. Bisphenol S and Epidermal Growth Factor Receptor Signaling in Human Placental Cytotrophoblasts. Environ. Health Perspect. 2021, 129, 027005. [CrossRef]

121. Aker, A.M.; Ferguson, K.K.; Rosario, Z.Y.; Mukherjee, B.; Alshawabkeh, A.N.; Calafat, A.M.; Cordero, J.F.; Meeker, J.D. A repeated measures study of phenol, paraben and Triclocarban urinary biomarkers and circulating maternal hormones during gestation in the Puerto Rico PROTECT cohort. Environ. Health 2019, 18, 28. [CrossRef]

122. Pepels, P.P.L.M.; Spaanderman, M.E.A.; Hermus, A.R.M.M.; Lotgering, F.K.; Sweep, C.G.J. Placental urocortin-2 and -3: Endocrine or paracrine functioning during healthy pregnancy? Placenta 2010, 31, 475-481. [CrossRef]

123. Peretz, J.; Vrooman, L.; Ricke, W.; Hunt, P.A.; Ehrlich, S.; Hauser, R.; Padmanabhan, V.; Taylor, H.S.; Swan, S.; Vandevoort, C.A.; et al. Bisphenol A and Reproductive Health: Update of Experimental and Human Evidence, $2007-2013$. Environ. Health Perspect. 2014, 122, 775-786. [CrossRef] 